\title{
Autologous Colon Cancer Cell Vaccine
}

National Cancer Institute

\section{Source}

National Cancer Institute. Autologous Colon Cancer Cell Vaccine. NCI Thesaurus. Code C1984.

A personalized, proprietary cancer vaccine composed of sterile, irradiated, non-dividing, live colon cancer cells obtained from an individual after tumor resection, with potential immunoactivating and antineoplastic activities. Upon intradermal administration, the autologous colon cancer cell vaccine activates the immune system and elicits a cytotoxic T-lymphocytic (CTL) response ag ainst the residual colon cancer cells, which results in tumor cell death. This may prevent cancer recurrence. According to the vaccination schedule, the first two out of the four doses are co-administered with the immunoadjuvant bacillus Calmette-Guerin (BCG), which is an attenuated strain of Mycobacterium bovis that non-specifically enhances the immune response. 